\title{
IMMUNOSUPPRESSIVE EFFECT OF POLYCYCLIC AROMATIC HYDROCARBONS BY INDUCTION OF APOPTOSIS OF PRE-B LYMPHOCYTES OF BONE MARROW
}

\author{
Jakub Novosad ${ }^{1}$, Zdeněk Fiala ${ }^{2}$, Lenka Borská ${ }^{3}$, Jan Krejsek ${ }^{1}$
}

Charles University in Prague, Faculty of Medicine in Hradec Králové: Institute of Clinical Immunology and Allergology ${ }^{1}$, Institute of Hygiene and Preventive Medicine ${ }^{2}$, Institute of Pathological Physiology ${ }^{3}$

Summary: Polycyclic aromatic hydrocarbons (PAH) are ubiquitous environmental pollutants, distinguished by genotoxic, hepatotoxic, nephrotoxic and immunotoxic effects. Especially secondary toxicity after bioactivation by microsomal monooxygenases (dependent on cytochromes P450) is characteristic of them. The immunotoxic effect is the result of very global impact on immunological reactivity of an organism and immunosuppression by induction of apoptosis of pre-B lymphocytes represents one of its particular forms. It has been proved that the effect of PAH is caused mostly by the following mechanisms: enzymatic induction by the way of activation of AhR (Aromatic hydrocarbon Receptor); alteration of cellular DNA; development of oxidative stress; increase in the concentration of intercellular calcium and decline of activity of NF-KB (Nuclear Factor - kappa B). Most sensitive to these changes are particularly B-lymphocytic precursors and pre-B lymphocytes. Intensity of entire manifestations is also considerably dependent on the presence and intensity of mechanisms of active or passive resistance of cells.

Key words: Polycyclic aromatic hydrocarbons; Immunosuppression; pre-B lymphocytes; Apoptosis

\section{Introduction}

PAH are ranked among ubiquitous environmental pollutants. They arise and get into life environment mostly by imperfect burning of fossil fuels, gases, wood but also a lot of other organic materials, especially tobacco (10). From a chemical point of view it is a very heterogeneous group of organic materials that are composed of at least two condensed benzene nuclei on which various substituents can be bound. PAH are considerably lipophilic. They enter an organism through the skin, by respiratory and gastrointestinal systems. Because of their physicochemical attributes they are able to get through the membranes very easily, without participation of active transporters (38).

\section{Toxicity of polycyclic aromatic hydrocarbons}

A much-discussed problem in connection with PAH is their toxicity for living systems. Primary toxicity (the toxicity PAH in the form in which they enter an organism) is relatively low. During biological experiments in rodents it has been proved that tissue damage with ultimate death have not been distinct until the quite high dose, calculated per kilogram of body weight (38). After the biotransformation to active metabolites (secondary toxicity) the toxicity of PAH rises very intensively and even at low doses it is possible to observe the disorders on sub cellular, cellular and organ levels. The damage of DNA - genotoxicity (and it implicates mutagenicity and potential carcinogenicity) - is among the most important toxic manifestations. Of organs, which are the most usually affected by PAH is necessary to mention liver (hepatotoxicity), kidney (renal toxicity) and immune system (immunotoxicity) $(4,11,37,38)$

\section{Bioactivation of polycyclic aromatic hydrocarbons}

In cytoplasm PAH induce a sequence of biological reactions whose products are molecules or molecular fragments with higher toxicity than the toxicity of the substances entering the reactions (bioactivation). The activity of the process mentioned above is different in different tissues in dependence on the expression of specific enzymes $(11,16)$.

The metabolism of PAH is not basically different from the metabolism of any other xenobiotic. The first phase is the oxidation by one of the enzymes of a large family of cytochromes P450 which give a rise to phenols, dihydrodiols and epoxides. The second phase is their conjugation with sulfates, glutathione or glucuronic acid which gives a rise to water soluble conjugates which are excluded in urine.

The activity of cytochromes P450 seems to be necessary for biological effects of PAH because of the characte- 
ristic electrophilic attributes of their metabolites. These attributes are given by the rise of an atom, missing an electron in its valence orbital (17). The electrophiles are very potent reactants which react with molecules rich in electrons - the nucleophiles - and create covalent adducts. Even the nuclear DNA is among these nucleophiles. Highly reactive free oxygen radicals, which are responsible for the development of oxidative stress, are the byproducts of oxidizing reactions mentioned above (28).

\section{The group of cytochromes $P 450$}

Cytochromes P450 create a group of hemoproteins, which catalyze the oxidation of many endogenous molecules and xenobiotics. They are located predominantly in the endoplasmic reticulum of hepatocytes but they are also probably present in all the other cells (17). They have been subdivided into the families according to their structural characteristics. In human body there are mostly the families CYP1, 2 and 3. These are divided into the several subfamilies from which CYP1A1 (with substantial expression in different tissues), CYP1A2 (expressed mostly in a liver) and CYP1B1 are the most important enzymes for the metabolism of PAH. CYP1B1 is a recently described cytochrome, very strongly expressed in the cells of bone marrow (14). The expression of all those enzymes (mentioned above) is PAH inducible.

\section{Immunotoxicity of polycyclic aromatic hydrocarbons}

It is provable that immune system is damaged by exposure to PAH (21). This damage is expressed by immunopathological reactivity - as its gain (which can be clinically expressed as an allergy) or its dilution, which leads to the immunosuppression. The immunosuppression more or less generally affects single components of immune system with consequently increased susceptibility to infections or tumor proliferation. Mechanisms of the effect are different and in many cases very hardly definable and clinically provable. In addition, these mechanisms are usually combined to the final effect (5). The most important impacts include reduction of the thymus and the bone marrow cells due to the apoptotic death of precursor cells of $\mathrm{T}$ and $\mathrm{B}$ lymphocytes $(40,22)$, alteration of antigen - receptor signaling, augmentation of another signaling pathways, interference with calcium metabolism (6) and impairment of the cytokine network by changes of level of some cytokines, particularly of interleukins 1 and 2 (38). According to some authors it is possible to observe the evident relationship between carcinogenity and immunosuppressive potential $(4,11,37)$.

\section{Molecular mechanisms of biological effects of PAH}

As it was mentioned above, due to their lipophilic character, $\mathrm{PAH}$ are able to enter a biomembrane without a particular transporter. After the entry to the cytoplasm they start a lot of processes of which the activation of AhR
(Aromatic hydrocarbon Receptor) (26), bioactivation of selected cytochromes, genotoxic effect of metabolites, development of the oxidative stress (28), impairment in the cellular homeostasis of calcium $(7,32)$ and even a decrease in the activity of nuclear factor NF-KB (23) are essential for the eventual effect.

\section{Functions of AhR, enzymatic induction}

$\mathrm{AhR}$ is the intracytoplasmatic molecule belonging to the group of proteins/transcription factors Per/ARNT/Sim. In a resting phase, it is associated with stress protein Hsp90 and with molecule ARA9/XAP-2 (hepatitis B virus X-associated protein 2). Attachment of PAH is followed by release of AhR from the bond and its own translocation to the nucleus with the help of transporter ARNT (aryl/aromatic hydrocarbon receptor nuclear translocator) (22). In the nucleus, AhR interacts with nucleotides sequence called DRE (dioxin response elements; dioxin is a model ligand of AhR). DRE impulses regulate the group of genes, marked as AhR-gene battery. It consists of at least six genes which code enzymes that take part - more or less - in the metabolism of PAH, of which CYP1A1, CYP1A2 (28) and CYP1B1 (14) have to be stressed. The enzymatic induction by the activation of AhR mentioned above apparently modulates the reactivity of an organism to long-lasting exposure to PAH. However, it has been shown that it is not an essential variable for induction of apoptosis of preBlymphocytes derived from the bone marrow and even more for apoptosis of experimental $\mathrm{T}$ - cell hybridoma $(14,22,40)$.

\section{Genotoxicity}

Genotoxicity of PAH is understood as the ability of its active metabolites (particularly diols and epoxides) to damage the cellular DNA. The point mutations, DNA adducts formation, breaks of single-strand DNA and the chromosomal aberrations are induced by PAH (38). Predominant targets are the cells with active synthesis of DNA; it means the dividing cells, among them particularly lymphoid precursors. There can be a malignant transformation as well as an increased elimination of impaired cells by apoptosis, as a consequence of their genotoxic damage. It seems that in complex mixtures of $\mathrm{PAH}$, occurring in the environment, the genotoxic effects are mostly associated with the content of benzo(a)pyrene (11).

\section{Oxidative stress}

Oxidative stress is defined as a damage of a cell or an organism by free radicals. The free radicals are highly reactive molecules or molecular fragments, containing unpaired electron in its valencial orbital. They usually rise as byproducts of oxidative reactions particularly in course of the respiratory chain (physiologically, 2-5\% of oxygen is reduced univalently on arise of free oxygen radicals, so-called ROS - reactive oxygen species) and in oxidation of substrates, e.g. PAH, by cytochromes P450 (28). Under normal cir- 
cumstances there exists a balance between the production of ROS and activity of so-called scavengers (SOD, GPX, and catalase) and antioxidants (vitamins A, C, E, glutathione, methionin, cystein etc.). Only during their increased production (for example due to higher activity of cytochromes P450), they are responsible for the chemical degradation of numerous targets in the cell (9) and the positive transcriptial regulation of some genes, due to regulative motives from DNA, designated as ARE (antioxidants response elements) (28). The oxidative stress itself is very powerful inducer of apoptosis.

\section{Interference with level of intercellular calcium}

The deregulation of calcium homeostasis turns out to be a very important factor of toxicity of PAH metabolites (27). As it is proved below, the increased calcium ions concentration in cell is mediated by at least two mechanisms: first by its release from microsomes by the alteration of function of channel RyR1 (ryanodine receptor) (32) and second by the activation of protein kinase PTK with following activation of phospholipase $\mathrm{C}$ and mobilization of calcium which is dependent on production of inositoltriphosphate (IP3) (7).

Increase in the level of calcium is very stressful for the cell, especially for the risk of exhaustion of energetic reserves, dysfunction of microfilaments and the activation of hydrolytic enzymes (17). It is also a characteristic feature of the apoptosis.

\section{Role of $\mathrm{NF}-\kappa \mathrm{B}$ transcription factor}

The role of nuclear factor kappa B, as an important factor for survival of the cell, has already been discussed in association with its antagonistic effect on apoptosis. It has been proved that the nuclear factor kappa B is able to inhibit apoptosis of cells induced by specific extracellular proapoptotic stimuli TNF- $\alpha$ and IL- $1 \alpha$ (2). Conditions associated with down regulation of activity of NF- $\kappa \mathrm{B}$ lead to depression of life span of the cells. One of the examples is even the exposure to PAH. Mechanism mentioned above takes also part in the whole immunosuppressive effect, caused by apoptotic death of pre-B lymphocytes (23).

\section{Apoptosis}

Apoptosis can be defined as a particular form of genetically regulated cell death. In a life of an organism it has absolutely essential role to keep a tissue homeostasis, and an optimal number of functional cells. It represents the contrary to the mitosis. Physiologically, it occurs either regulated (elimination of the cells during embryonic development - programmed cellular death) or repressive, not regulated mechanism for removing of insulted cells either virally infected or malignantly transformed (unprogrammed cellular death) (35).

Under pathological conditions, in the case of its deregulation, apoptosis could be at the beginning and the deve- lopment of illness (for example proliferation of malignantly transformed cell clone is associated with the loss of apoptotic potential or on the other hand, neurodegenerative diseases cause the excessive apoptotic death).

Apoptosis progresses with the highly conservative phylogeneticaly script. The basic principle of that script is a gradual activation of specific genes and proteins. In the end, there is a coordinated cleavage of cellular structures, which is energy dependent $(29,30)$.

\section{Phases of apoptosis}

The cell in the course of apoptosis goes through these two phases: signaling and effector's one. During the signaling phase, numerous signals and information are processed in the cell to testify in or out cell's favor. They are either extracellular or intracellular. They can be either specific (TNF $\alpha$, FasL, growth factors) or nonspecific (metabolism failure or DNA damage). Only after their summation - in the case of proapoptotic information prevalence - the cell enters the second phase. The activation of latent cystein proteases - caspases, is the hallmark of this process (12).

Characteristic signs of the process mentioned above are: the development of oxidative stress, which takes part in the degradation of some cellular organelles (9), the increase in intracellular calcium level and the increase in permeability of mitochondrial membranes (8).

\subsubsection{Internal pathway of apoptosis, protein p53}

Any change of internal environment represents a risk for keeping the integrity of the whole organism. As a most common example it is possible to stress the random mutation of genome, caused by fault in the replication of DNA or during the process of gene segments rearrangement. On this condition, the protective cell mechanisms are immediately activated. The cell cycle progress is stopped in attempt to repair the errors. If genetically defaults are irreparable, the altruistic suicide of cell by apoptosis is induced $(13,33,39)$.

The gatekeeper of integrity of genome, which initiates the processes mentioned above, is p53 protein. It is a tumor suppressor protein with molecular weight $53 \mathrm{kDa}$. The p53 protein is bound to DNA by the area adjacent on C-end (rich on basic amino acids) where it is possible to detect the damaged area. In the same time that protein can immediately initiate the DNA reparation (13).

In the case that DNA damage exceeds the frame of easy reparation the expression of the $\mathrm{p} 53$ protein increases and it takes its function as a transcription factor. As a first step it is possible to detect the increase in the expression of $\mathrm{p} 21$ protein (blocker of cycline dependent kinase). This protein is able to stop the cell growth and division and also provides sufficient time for more effective reparation of DNA. The production of the other proteins (particularly so-called PIGs genes - p53 induced genes) which are functionally closely associated with development of the oxidative stress, followed by the entrance into apoptosis, increase immedia- 
tely if genetic damage is irreversible. $(13,20,28)$. It is being proved that the oxidative stress, is the key moment that decides about the fate of a cell.

\section{Regulation of apoptosis}

Integral part of either signaling or effector's phase is presented by the factors-proteins regulating apoptosis. These proteins block the intracytoplasmatic transduction of internal specific proapoptotic stimuli (proteins FLIPs and SODD) (35). Numerous proapoptotic (for example Bax) and antiapoptotic (for example Bcl-2) molecules belong to Bcl-2 family $(8,15)$. Their right timed expression and mutual rate is also essential for normal development of B-lymphocytes in the bone marrow.

As it was mentioned above, some of the nuclear factors (particularly NF- $\kappa \mathrm{B}$ ) play an important role in the regulation of apoptosis.

\section{Differentiation of B-lymphocytes in bone marrow}

Precursors of B-lymphocytes are developed in the bone marrow by division of hematopoietic stem cells. They gradually differentiate through several stages - proB, preB and immature B-lymphocytes, which leave the bone marrow and settle secondary lymphatic tissues. During their development in bone marrow they create specific receptor for antigen (BcR), by the mechanism of the gene segments rearrangement and they become the immunocompetent cells. This process is essential for maturing of B-lymphocytes and it is tightly regulated.

$\mathrm{BcR}$ is a surface molecule with the immunoglobulin structure, which consist - similarly as secretory immunoglobulins - of two heavy and two light chains. An additional chain, which serves for stabilization in the membrane, two molecules marked as Ig $\alpha$ (CD79a) and two molecules $\operatorname{Ig} \beta$ (CD79b) create also an integral part of BcR. That receptor is expressed at first as a pre-BcR and later in the form of BcR on the surface (25).

\section{Role of microenvironment}

The bone marrow microenvironment provides optimum conditions for maturation of B-lymphocytes. It produces growth factors which stimulate division and differentiation of B-lymphocytes (particularly IL-7 and CSF-1) (20) and inhibit their death by the apoptosis. In a case of any damage of the microenvironment, apoptosis can take part in inhibiting of the development and in eliminating of nonfunctional (and partly even autoreactive) clones of B lymphocytes (3).

\section{Physiological importance of apoptosis for development of B-lymphocytes}

It has been proved that BcR gene rearrangement generates a huge amount of errors leading to the both syntheses of nonfunctional $\mathrm{BcR}$ and syntheses of $\mathrm{BcR}$ with very high affinity to the self antigens. That's why it is necessary to ensure that during the development of B-lymphocytes there are several checkpoints where the mistakes can be removed or where insulted and dangerous cells can be eliminated (19).

Studies on the model of mouse bone marrow have proved that these points are at least two: 1) on the middle way from pro-B to pre-B lymphocyte when the first surface expression of newly synthesized heavy chain " $\mu$ " may happen and 2) at lymphocytes with low expression of $\operatorname{sIgM~(BcR),~}$ it means at immature but already immunocompetent cells (20).

The control of the errors and the elimination of the injured cells by apoptosis become at both checkpoints. Almost $70 \%$ of cells die through this mechanism even in the first point which represents about 51 million of pre-B lymphocytes per day (20). In this content it is necessary to mention very important role of protein p53 $(13,19)$.

The cells at the checkpoints show quite unique characteristics. The levels of proteins, which regulate the apoptotic changes, are variable. Production of Bcl-2 decreases and expression of the Bax protein increases. The ratio of $\mathrm{Bcl}-2 / \mathrm{Bax}$ is remarkable decreased but proapoptotic potential of these two precursors is increased (20). They are vulnerable and they easy yield to the exogenous apoptotic stimuli.

\section{Pathological induction of apoptosis dependent on function of bone marrow}

For the study of induction of apoptosis of pre-B lymphocytes a model system, based on the cellular structure of BMS2 (stroma cells of bone marrow) has been developed $(14,22,23)$. On the basis of many studies, following conclusions could be drawn:

1) Apoptosis of pre-B lymphocytes is dependent on the cellular stroma. Only relatively high doses of PAH lead to the death of B-lymphocytes cultivated without presence BMS2 (22).

2) The bioactivation of PAH is important for induction of the apoptosis. Only the active metabolites of PAH (dihydrodiols and epoxides) are very potent inducers. This finding confirms the importance of cytochromes P450 (22).

3 ) From point of view of the general activity of cytochromes (in the association with apoptosis) basal expression of cytochromes plays more important role than their induction by the way of AhR. The activation AhR it-self is not sufficient for the immunosuppressive effects (22).

4) CYP1B1 seems to be the key enzyme that shows quite high activity especially in the stromal cells of bone marrow. Toxic metabolites created by presence of that enzyme are able to get into the cytoplasm of the lymphocytes and cause the genotoxic damage of DNA. From this point of view the role of the other enzymes is negligible (14). 
5) The depression of activity of NF-кB and defects in the calcium metabolism take also part in the final effect (23).

From these facts we can draw out that the apoptosis of pre-B lymphocytes happen probably on the base of: 1) transduction of toxic PAH metabolites from the bone marrow stromal cells, 2) development of oxidative stress, 3 ) defects of calcium homeostasis and 4) depression of activity of NF-кB transcription factor in lymphoid precursors.

Pre-B lymphocytes are - due to their high proapoptotic potential and their replicate activity - the most sensitive to the effect of PAH.

\section{Mechanisms of protection}

Because of the considerable heterogeneity of the intensity in the clinical and laboratory manifestations of immunosuppressive effect of PAH it is necessary to discuss the most important modulating factors of individual reactivity of an organism. Besides the variable ability of induction of the enzymes from the group of cytochromes P450 (different response to activation of AhR), even the processes of detoxification of bioactivated metabolites, the proapoptotic potential of pre-B lymphocytes and some forms of the active cellular defense come to account.

\section{Enzymatic equipment, detoxification}

Highly reactive intermediate products that have an electrophilic or radical character rise during the metabolism of $\mathrm{PAH}$. The cells have numerous enzymes and cofactors of enzymes that are able to reduce the toxic effect of PAH.

For the elimination of free radicals the cytoplasm reserves of antioxidants and so-called scavengers (enzymes which catalyze gradual conversion of free oxygen radicals to water) are the most important. Superoxid-dismutase (SOD), glutation-peroxidase (GPX) and catalase belong among the free oxygen radical scavengers (17).

For the detoxification of electrophiles the most important are next two enzymes: 1) glutathion-S-transpherase and 2) epoxid-hydrolase. Glutathion-S-transpherase (Gsta1) catalyzes their conjugation with nucleophilic glutathione. It is interesting that Gstal is prone to the enzymatic induction due to the both motives DRE (part of AhR-gene battery) and ARE (positive regulated by oxidative stress) (17, 28). The epoxid hydrolase catalyze trans-addition of water to epoxid group on arise of non-toxic alcohols. This is the way to reduce the risk of DNA damage by epoxides. It occurs in almost all tissues and its distribution is parallel with occurrence of cytochromes P450 (17).

\section{Proteins regulating apoptosis}

As it was mentioned, the fate of a cell is - in the association with apoptosis - dependent on many factors. The well-balanced co-expression of proteins from the $\mathrm{Bcl}-2 \mathrm{fa}-$ mily, of which the principal representative is the protein Bcl-2 with the antiapoptotic effect, belongs among the most important factors. All the members of this group are connected by the common characteristic structural trait - $\mathrm{BH} 1$ and $\mathrm{BH} 2$ domains. These domains serve to mutual dimerisation and inactivation. By this mechanism, protein Bcl-2 (important inhibitor of apoptosis) can be for example discarded from the function by the proapoptotic protein Bax. It is the mutual rate of single members of this group that decide about survival or death of the cell under the various conditions $(8,15)$.

It is worth mentioning that the protein Bax is prone to transcriptial induction by protein p53 (13). Except for another functions, protein Bcl-2 affects as an antioxidant and as a channel for calcium ions modulates their level in cytoplasm (8).

\section{Active defense}

Except for all mentioned mechanisms of passive defense of the constant intracellular environment (detoxification and elevation of the cellular life span by inhibition of apoptosis) there exist also effective means of active defense in a form of energy dependent efflux transport systems. In this consequence the importance of the expression and function of membrane protein P-gp (P-glycoprotein) is stressed (34)

\section{P-glycoprotein}

P-glycoprotein (P-gp, p170) is a membrane phosphoglycoprotein, from the ABC (ATP-binding cassette) family of transmembrane proteins. P-gp is expressed on the cell surface and it serves as on ATP dependent pump. Its function is to transport the xenobiotics from cytoplasm and thus reduce their concentration and their adverse effects. Expression P-gp was found on progenitor hematopoietic cells (CD34+), on peripheral lymphocytes and also on many other cells. Its function is to protect these cells against exogenic substances $(18,24)$. Recently the importance of this protein increases in the association with undesirable aspects of its occurrence - increasing resistance of tumor cells against therapy by cytostatic drugs.

Because of the transport function of P-gp, various chemical compounds with aromatic circle(s) were intensively studied in the past (18). On the biological models it was proved that PAH are prone to efflux effect of P-gp (1) and that this effect can be even inducible by mechanism which is different from the way of activation of $\operatorname{AhR}(34,36)$. It has been proved that variable ability to inducing the expression of P-gp can be understood as a negative predictive risk factor for the toxic effects of PAH (34). However, some works do not support this opinion (31).

\section{Conclusion}

PAH disturb immunological activity of an organism in a very complex way. Immunosuppressive effect by induction of apoptosis of pre-B lymphocytes is just one of many effects, resulted from immunotoxic influence of PAH. As it 
was mentioned above, even here exists a considerable variability and individuality in sensitivity of the organism to the penetration of PAH. This sensitivity is given particularly by a) own primary and secondary toxicity of PAH and b) by active and passive resistance of the cells. It is impossible to forget also the very difficult context of mutual relationship between both particular parts of immune system and immune system as a whole and the other functional units and structures of organism. To evaluate the clinical importance of exposure to PAH, it is necessary to understand that during their lives people are exposed to very hardly definable and standardisable mixtures of xenobiotics.

The research on influence of compounds like PAH to an immune system is profitable and contribute to further understanding of individual reactivity.

\section{References}

1. Bamdad M, Reader S, Groliere CA et al. Uptake and efflux of polycyclic aromatic hydrocarbons by Tetrahymena pyriformis: evidence for resistance mechanism. Cytometry 1997;28:170-5.

2. Beg AA, Baltimore D. An essential role for NF-kappaB in preventing TNF-alphainduced cell death. Science 1996;274:782-4.

3. Bertrand FE, Eckfeldt E, Fink JR et al. Microenviromental influences on human B cell development. Immunol Rev 2000;175:175-86.

4. Boháčová S, Borská L, Fiala $\mathrm{Z}$, Andrýs C. Vliv polycyklických aromatických uhlovodíků na imunitní systém. Acta Med. (Hradec Králové) Suppl 1999;42(1): 444-72.

5. Borská L, Andrýs $\mathrm{C}$, Fiala $\mathrm{Z}$ et al. Imunologický profil u mužů profesionálně exponovaných imisím ze sváření nerezových oceli. Pracov Lék 2000·52(2):63-8.

6. Burchiel SW, Luster MI. Signaling by enviromental polycyclic aromatic hydrocarbons in human lymphocytes. Clin Immunol 2001;98 (1):2-10.

7. Davila DR, Lane JL, Lauer FT et al. Protein kinase activation by polycyclic aromatic hydrocarbons in human HPB-ALL T cells. J Toxical Envirom Health A 1999; 56(4):249-61.

8. Dive C. Avoidance of apoptosis as a mechanism of drug resistance. J Int Med 1997;242:139-45.

9. Favier A. Oxidative stress: value of its demonstration in medical biology and problems posed by the choice of a marker. Ann Biol Clin 1997;55:9-16.

10. Fiala Z, Vyskočil A, Kraják V et al. Polycyklické aromatické uhlovodíky I. Kontaminace prostředí a expozice osob. Acta Med (Hradec Králové) Suppl 1999;42(2):77-89.

11. Fiala Z, Borská L. Polycyklické aromatické uhlovodíky II. Toxické účinky. Acta Med (Hradec Králové) Suppl 2000;43(3):37-61.

12. Fraser A, Evan G. A licence to kill. Cell 1996;85(6):781-4.

13. Harris CC. Structure and function of the p 53 tumor supressor gene: clues for rational cancer therapeutic strategies. J Nat Canc Ins 1996;88(20):1442-55.

14. Heidel SM, Holston K, Buters JTM et al. Bone marrow stromal cell cytochrome P4501B1 is required for pre-B cell apoptosis induced by 7,12-dimethyl-benz[a]anthracene. Mol Pharmacol 1999;56:1317-23.

15. Hockenbery D, Nunez G, Milliman C et al. Bcl-2 is an inner mitochondrial membrane protein that blocks programmed cell death. Nature 1990;348(6299):334-6.

16. Holoubek I. Polycyklické aromatické uhlovodíky (PAHs) v prostředí. 1.vydání Praha: Český ekologický a odbor ekologických rizik a monitoringu MŽP ČR $1996 ; 134$

17. Klaasen CD, Amdur MO, Doull J. Casarett and Doull's toxicology - the basic science of poisons. Fifth edition. London: McGrow-Hill Companies, Inc. 1996;854.

18. Kodydková K, Krejsek J. Rezistence buněk krevních malignit vůči cytostatikủm. Čas Lék Čes 2000;139(18):553-6.

19. Lu L, Lejtenyi D, Osmond DG. Regulation of cell survival during B lymphopoiesis: supressed apoptosis of pro-B cells in P53-deficient mouse bone marrow. Eur J Immunol 1999;29:2484-90.
20. Lu L, Osmond DG. Apoptosis and its modulation during B lymphopoiesis in mouse bone marrow. Immunol Rev 2000;175:158-74.

21. Luster M, Rosenthal GJ. Chemical agents and the immune response. Environ Health Respect 1993;101:219-26.

22. Mann KK, Matulka RA, Hahn ME et al. The role of polycyclic aromatic hydrocarbon metabolism in dimethylbenz[a]anthracene-induced pre-B lymphocyte apoptosis. Toxicol and Appl Pharmacol 1999;161:10-22.

23. Mann KK, Doerre S, Shlezinger JJ et al. The role of NF-KB as a survival factor in enviromental chemical-induced pre-B cell apoptosis. Mol Pharmaco 2001;59:302-9

24. McKenna S. Multidrug resistance in leukemia. Br J Haematol 1997;96:659-74.

25. Mokrý J. Vývoj B - lymfocytů v primárních a sekundárních lymfatických orgánech. Lék Zpr LF UK HK 1997;42(5-6):111-20.

26. Near RI, Matulka RA, Mann KK et al. Regulation of preB cell apoptosis by aryl hydrocarbon receptor/transcription factor - expressing stromal/adherent cells. Proc Soc Exp Biol Med 1999;221(3):242-52.

27. Nebert DW, Puga A, Vasiliou V et al. Role of the Ah receptor and the dioxin-inducible $[\mathrm{Ah}]$ gene battery in toxicity, cancer and signal transduction. An NY Acad Sci 1993;685:624-40.

28. Nebert DW, Roe AL, Dieter MZ et al. Role of the aromatic hydrocarbon receptor and $[\mathrm{Ah}]$ gene battery in the oxidative stress response, cell cycle control, and apoptosis. Biochem Pharmacol 2000;59:65-85.

29. Novosad J, Kodydková K, Krejsek J. Apoptóza, její mechanismy a medicínský význam. I. Definice apoptózy a jeji průběh na buněčné úrovni. Vnitř Lék 2001;47(6):381-6.

30. Novosad J, Kodydková K, Krejsek J. Apoptóza, jeji mechanismy a medicínský význam. II. Poruchy regulace apoptózy a jejich souvislost s rozvojem onemocněni. Vnitř Lék 2001;47(6):387-90.

31. Payen L, Courtois A, Langouet S et al. Unaltered expression of multidrug resistance transporters in polycyclic aromatic hydrocarbon-rezistant rat liver cells. Toxicol 2001;156(2-3):109-17.

32. Pessah IN, Beltzner C, Burchiel SW et al. A bioactive metabolite of benzo[a]pyrene, benzo[a]pyrene- 7,8-dione, selectively alters microsomal $\mathrm{Ca}(2+)$ transport and ryanodine receptor function. Mol Pharmacol 2001;59(3):506-13.

33. Polyak K, Xia Y, Zweier JL et al. Amodel for p53 - induced apoptosis. Nature 1997;389(9):300-5.

34. Schuetz EG, Schuetz JD, Thompson MT et al. Phenotypic variability in induction of $\mathrm{P}$ glycoprotein mRNA by aromatic hydrocarbons in primary human hepatocytes. Mol Carcinog 1995; 12(2):61-5.

35. Vaux DL. Immunopathology of apoptosis - introduction and overview. Spring Semin Immun 1998;19:271-8.

36. Waldmann P, Pivcevic B, Muller WE et al. Increased genotoxicity of acetylaminofluorene by modulators of multixenobiotic rezistance mechanism: studies with the fresh water clam Corbicula fluminea. Mutat Res 1995;342(3-4):113-23.

37. WHO. Enviromental Health Criteria 202: Selected Non-heterocyclic Polycyclic Aromatic Hydrocarbons. Geneva: WHO 1998;187.

38. WHO. Enviromental Health Criteria 180: Principles and Methods for Assessing Direct Immunotoxicity Associated with Exposure to Chemicals. Geneva: WHO 1996;203.

39. Wyllie A. Clues in the p53 murder mystery. Nature 1997;389(9):237-8.

40. Yamaguchi K, Near R, Shneider A et al. Fluoranthene-Induced Apoptosis in Murine T Cell Hybridomas Is Independent of the Aromatic Hydrocarbon Receptir. Toxicol and Appl Pharmacol 1996;139:144-52.

Submitted March 2002.

Accepted September 2002.

MUDr. Jakub Novosad,

Charles University in Prague,

Faculty of Medicine in Hradec Králové,

Institute of Clinical Immunology and Allergology, 50005 Hradec Králové, Czech Republic. e-mail: ukia@fnhk.cz 